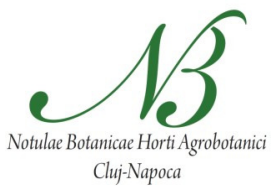

\title{
Rapid Propagation of Sweet and Sour Cherry Rootstocks
}

\author{
Dušica DORIĆ ${ }^{1 *}$, Vladislav OGNJANOV ${ }^{1}$, Mirjana LJUBOJEVIĆ ${ }^{1}$, Goran BARAĆ ${ }^{1}$, \\ Jovana DULIĆ ${ }^{1}$, Ankica PRANJIĆ ${ }^{2}$, Krunoslav DUGALIĆ ${ }^{2}$ \\ ${ }^{1}$ University of Novi Sad, Faculty of Agriculture, Department of Fruit Science, Viticulture, Horticulture and Landscape Architecture, Dositej Obradovic Sq. 8, \\ 21000 NoviSad,Serbia; dusicab@polj.uns.ac.rs(correspondingauthor),vognjanov@polj.uns.ac.rs, \\ ikrasevm@polj.uns.ac.rs, goranb@polj.uns.ac.rs,jovanadulic87@gmail.com \\ 2Agricultural Institute Osijek,Department of Fruit Science,Juznopredgradje17,31000 Osijek, Croatia; ankica.pranjic@polinos.hr, krunoslav.dugalic@poljinos.hr
}

\begin{abstract}
The paper presents a protocol for micropropagation of Prunus sp. rootstocks included in the sweet and sour cherry breeding program. Germplasm diversity for rootstock breeding derives from natural populations, where conditions and biological vectors for systematic infection with viral diseases are constantly present. The establishment of aseptic culture depends primarily on the explant type, as all selections were collected from natural habitat. For nearly all investigated selections, dormant buds were the favored source, due to enabling rosette initiation in more than $58 \%$ cases. In $P$. cerasus $\mathrm{L}$. selections, $100 \%$ contamination was noted when shoot tips were used as an explant source. Significant influence of the doublephase medium on the number and height of multiplied shoots was observed in the standard cherry rootstock, 'Gisela 6 '. For $P$. fruticosa Pall., selection 'SV1' and 'SV2', and $P$. cerasus 'D6' selection, the double-phase medium also had a significant effect on the height of multiplied shoots, when compared to solid DKW (Driver and Kuniyuki Walnut) medium. Genetic variability of selections within the investigated species resulted in variable plant rooting success. Adding Fe-EDDHA (Ethylenediamine di2-hydroxy-phenyl acetate ferric) in the $200 \mathrm{mg} \mathrm{l}^{-1}$ concentration to the rooting medium significantly enhanced the percentage of rooted plants. The highest rooting percentage was noted for 'Gisela 6 ' and 'D6' genotype at $1 \mathrm{mgl}^{-1} \mathrm{IBA}$ (indole-3-butyric acid), while $0.8 \mathrm{mg} \mathrm{l}^{-1}$ was the optimum concentration for $P$. mahaleb L. 'M1' selection. $P$. fruticosa genotypes required significantly higher IBA concentration for rooting $\left(2.5\right.$ and $\left.3.5 \mathrm{mg} \mathrm{l}^{-1}\right)$.
\end{abstract}

Keywords: clonal multiplication, juvenility, plant growth regulators, tissue culture

Abbreviations: BA: 6-benzyladenine; DKW: Driver and Kuniyuki Walnut medium; Fe-EDDHA: Ethylenediamine di-2hydroxy-phenyl acetate ferric; $\mathrm{GA}_{3}$ : Gibberellic acid; IBA: Indole-3-butyric acid; MS: Murashige and Skoog; NAA: 1naphtaleneacetic acid; SH: Schenk and Hildebrandt

\section{Introduction}

Every potential new rootstock has to be subjected to a long-term evaluation process that requires considerable space, time and knowledge, as well as extensive financial investment (Ljubojević et al., 2013). Selection success in breeding of vegetative rootstocks for sweet and sour cherry is dependent not only on genetic variability, but also on expediting propagation processes as a precondition for investigation of specific combining abilities between rootstock and scion (Bošnjaković et al., 2012b; Bošnjaković et al., 2013).

Biodiversity of wild fruit species provides an inexhaustible gene pool for breeding work in Prunus sp. (Paunović, 2008; Bošnjaković et al., 2012a). There is a tremendous opportunity for genetic improvement and utilization of $P$. mahaleb L., $P$. cerasus L., and $P$. fruticosa Pall. genotypes to facilitate rootstock breeding. Conventional germplasm preservation and clonal propagation activities in rootstock breeding mandate that several years are dedicated to ex situ conservation and clonal propagation by stool beds, soft or hardwood cuttings. In vitro plants can be used for ex situ conservation of genetic resources on their own roots, thus replacing standard propagation by grafting.

Micropropagation is a widely used method for multiplication of standard rootstocks, as well as for new plant cultivars and rootstock selections (Dradi et al., 1996; Pruski et al., 2005; Vujović et al., 2012; Druart, 2013). However, it is possible to propagate plants throughout the entire year, whereby the multiplication rate significantly 
489

exceeds that of vegetative propagation by cuttings. As a universal medium for in vitro plants does not exist, selection of appropriate medium, plant growth regulators and other components that could enhance plant production is very important (Ružić et al., 2000; Rustaei et al., 2009; Hossini et al., 2010). Some authors recommend adding activated charcoal into the liquid medium as a means to enhance elongation and multiplication rate (Jona and Vigliocco, 1985; Hassan and Roy, 2005), while some others posit that supplementation by different iron sources can increase the number of rooted plants (Dimassi et al., 2003; Molassiotis et al., 2003; Molassiotis et al., 2004; Trejgell et al., 2012). Presently, there is paucity of studies investigating the effect of introducing iron into the rooting medium for sweet and sour cherry rootstocks. Aghaye et al. (2013) reported achieving $100 \%$ rooting in 'Gisela 6' using different thiamine and Fe-EDDHA concentrations. As sweet cherry rootstocks are cited as difficult to root (Feucht and Dausend, 1976; Štefančić et al., 2007; Sedlak et al., 2008), an efficient propagation method of new rootstock selections is needed.

The aim of this study was to develop protocol for micropropagation of selections included in the rootstock breeding program discussed in this work. The focus was on examining the influence of the double-phase medium on the multiplication index as well as the effects of FeEDDHA on rooting of rootstock selections for sweet and sour cherry.

\section{Materials and methods}

\section{Plant material and culture establishment}

The dormant buds and actively growing shoot tips of 'Gisela 6' and five promising rootstock selections were used as initial explants. Dormant buds were collected at the end of December, while shoot tips were obtained in May from mature trees grown ex situ in the experimental field at the Faculty of Agriculture, Novi Sad.

The rapid multiplication and rooting ability of 'Gisela 6' and five selections - labeled as 'SV1' and 'SV2' from $P$. fruticosa (hereinafter referred to as 'SV1' and 'SV2'), 'M1', from $P$. mabaleb (henceforth - 'M1'), and 'D3' and 'D6' from $P$. cerasus (henceforth - 'D3' and 'D6') - were investigated. The surface sterilization was carried out using two different protocols - for dormant buds, and for actively growing shoot tips. Dormant twigs with one node were first rinsed in tap water for 2 hours, after which they were disinfected first - with fungicide Previcur ( $5 \%$ ) for 30 minutes, before being immersed in $0.1 \%$ mercuric chloride for 5 minutes. Sterilization was accomplished in laminar flow hood with $70 \%$ ethanol containing $0.1 \%$ Tween for 1 minute, followed by being placed in $4 \%$ sodium hypochlorite for 25 minutes, and finally subjected to 3 rinses with sterile distilled water. After peeling off the outer scales, the buds were again immersed in 70\% ethanol, and $4 \%$ sodium hypochlorite, this time for 5 minutes, followed by two rinses with sterile distilled water. Meristem dissection with 2-3 primordial leaves was performed under stereomicroscope and cultured on the initiation medium containing SH (Schenk and Hildebrandt, 1972) macroelements, MS (Murashige and
Skoog, 1962) microelements and vitamins, with (in $\mathrm{mgl}^{-1}$ ) 6benzyladenine (BA) 0.5, 1-naphtaleneacetic acid (NAA) 0.01 and gibberellic acid $\left(\mathrm{GA}_{3}\right) 0.5 \mathrm{mgl}^{-1}$. Sucrose $\left(30 \mathrm{gl}^{-1}\right)$ was used as a carbon source, solidified with $6.5 \mathrm{~g} \mathrm{l}^{-1}$ agar, with the $\mathrm{pH}$ value adjusted to 5.8 before autoclaving at $121^{\circ} \mathrm{C}$ and $100 \mathrm{kPa}$ for 25 minutes.

Shoot tip sterilization followed the standard procedure, whereby the explants were excised to $1.5 \mathrm{~cm}$ height, before being washed under running tap water for 2 hours, and disinfected first - with Previcur (5\%) for 30 minutes, and later using mercuric chloride $(0.1 \%)$ for 5 minutes. Under a sterile laminar flow hood, actively growing shoot tips were sterilized with $70 \%$ ethanol, containing $0.1 \%$ Tween for 1 minute, and in $4 \%$ sodium hypochlorite for 25 minutes. After rinsing in sterile distilled water three times, explants were cultured on the same initiation medium as dormant buds.

After three weeks on the initiation medium, the explants infection, initiation and browning rates were measured.

\section{Multiplication}

Multiplication parameters of the newly formed shoots were investigated on the solid and double-phase DKW (Driver and Kuniyuki, 1984) medium. Solid medium was supplemented with BA and indole-3-butyric acid (IBA) in the concentration of $0.8 \mathrm{mgl}^{-1}$ and $0.01 \mathrm{mg} \mathrm{l}^{-1}$, respectively, and sucrose and agar in the concentration of $30 \mathrm{~g} \mathrm{l}^{-1}$ and $6.5 \mathrm{~g} \mathrm{l}^{-1}$, respectively. Liquid medium contained double concentration of DKW macroelements, microelements and vitamins, as well as halfstrength BA concentration, supplemented with $2 \mathrm{~g} \mathrm{l}^{-1}$ active charcoal, with the $\mathrm{pH}$ value adjusted to 5.8 before autoclaving at $121^{\circ} \mathrm{C}$ and $100 \mathrm{kPa}$ for 20 minutes. Liquid medium did not comprise agar and sucrose. Approximately $20 \mathrm{ml}$ of liquid medium was added on the top of the solid medium. Multiplication index, length of the multiplied shoots exceeding $0.5 \mathrm{~cm}$, number of leaves, leaf width and leaf length were measured after four weeks on solid and double-phase multiplication medium.

\section{Rooting}

After multiplication on the solid medium, plants were placed on DKW hormone-free medium, aimed at improving shoot elongation before rooting. Shoots of the investigated genotypes were rooted on half-strength macro and micro MS elements, and vitamins, supplemented with $20 \mathrm{gl}^{-1}$ sucrose and $6.5 \mathrm{~g} \mathrm{l}^{-1}$ agar. Depending of genotype, different IBA (0.5-3.5 mg $\left.\mathrm{I}^{-1}\right)$ concentrations were used, and Fe-EDDHA in the concentration of $200 \mathrm{mg} \mathrm{l}^{-1}$ was added as an iron source. The $\mathrm{pH}$ of the medium was adjusted to 5.8 before autoclaving. After four weeks, the rooting percentage, number of roots and total root length were recorded. All cultures were incubated in an environmental chamber at $24 \pm 2{ }^{\circ} \mathrm{C}$ with $16 \mathrm{~h}$ photoperiod.

\section{Statistical analysis}

All collected data were analyzed by ANOVA, followed by the Duncan's multiple range tests, performed by STATISTICA 10.0 (StatSoft, Inc., Tulsa, OK, USA). Number of roots and root length were measured by 'ImageJ 1.44p' (Wayne Rasband, National Institute of Health, USA). 


\section{Results and discussions}

Making a correct choice of explants type has an important effect on the success of further tissue culture. Since all collected plant material used in this study originated from ex situ conditions, contamination was observed at all genotypes. Initiation from actively growing shoot tips, for 'D3' and 'D6', seems to be the least favourable choice, as it resulted in infection in $100 \%$ of the explants (Tab. 1). However, the advantages of using shoot tips over dormant buds include greater survival rate to in vitro conditions, more rapid growth onset, and a greater number of produced shoots. On the other hand, explants of a greater size tend to be more difficult to decontaminate (George and Debergh, 2008). With the exception of 'SV1', high percentage of contaminated explants was found in all other selections (79.3-95.0\%). Even though in vitro cultures can be established at any time of the year, the success rate depends on the season of explant collection (Dobránszki and Teixeira da Silva, 2010; Ružić et al., 2010). In buds $0.2-0.6 \mathrm{~cm}$ in length, Kaushal et al. (2005) reported 60\% survival rate, while nearly all 1-2 cm long explants died during subculturing. These findings are in line with our results pertaining to dormant buds, where rosette initiation success rate exceeded $57.7 \%$ in all cases, with the exception of 'D6' genotype. For apricot, Perez-Tornero et al. (1999) recommended establishing explants from meristem tip culture, indicating that, this technique has a potential for decreasing prevalence of explant infection. Our results indicate that winter months are more suitable for establishing explants in vitro, enabling higher rosette initiation, and achieving better multiplication scheduling. Until the end of December, due to the greater cumulative number of chilling hours, the growth inhibitor abscisic acid levels declined. However, the amount of both cytokinins and giberrelins subsequently increased, reaching the levels sufficient for normal shoot growth (Pruski et al., 2005). Meristem tip was the most suitable explant for cultures initiated from field-grown mother trees, which are putatively contaminated (Druart, 2013). Moreover, this timing enables transferring acclimatized plants into the field during spring. Explant browning was present when dormant buds were used as an explant source, possibly due to repeated disinfection with ethanol and sodium hypochlorite, which resulted in plant tissue damage. The most pronounced browning was observed in 'SV1' genotype (27.0\%).

Significantly better influence of double-phase medium on the number and height of newly formed shoots was noted at

Tab. 1. Establishment of aseptic culture from shoot tips and dormant buds

\begin{tabular}{|c|c|c|c|c|}
\hline Genotype & $\begin{array}{l}\text { Type of } \\
\text { explants }\end{array}$ & $\begin{array}{c}\text { Rosette } \\
\text { initiation (\%) }\end{array}$ & $\begin{array}{c}\text { Infected } \\
\text { explants (\%) }\end{array}$ & $\begin{array}{c}\text { Explant } \\
\text { browning }(\%)\end{array}$ \\
\hline \multirow{2}{*}{ 'Gisela 6} & Shoot tip & $12.3 b c$ & $87.7 \mathrm{ab}$ & - \\
\hline & Dormant bud & $75.0 \mathrm{a}$ & $10.0 \mathrm{~d}$ & $15.0 \mathrm{bc}$ \\
\hline \multirow{2}{*}{ 'D3' } & Shoot tip & $0.0 c$ & $100.0 \mathrm{a}$ & - \\
\hline & Dormant bud & $57.7 \mathrm{~b}$ & $31.0 \mathrm{~b}$ & $11.3 \mathrm{c}$ \\
\hline \multirow{2}{*}{ 'D6 } & Shoot tip & $0.0 \mathrm{c}$ & $100.0 \mathrm{a}$ & - \\
\hline & Dormant bud & $7.0 \mathrm{c}$ & $91.0 \mathrm{a}$ & $2.0 \mathrm{~d}$ \\
\hline \multirow{2}{*}{ 'M1' } & Shoot tip & $5.0 \mathrm{c}$ & $95.0 \mathrm{a}$ & - \\
\hline & Dormant bud & $63.3 \mathrm{~b}$ & $17.0 \mathrm{c}$ & $19.7 \mathrm{~b}$ \\
\hline \multirow{2}{*}{ 'SV1' } & Shoot tip & $48.3 \mathrm{a}$ & $51.7 \mathrm{c}$ & - \\
\hline & Dormant bud & $59.0 \mathrm{~b}$ & $14.0 \mathrm{~cd}$ & $27.0 \mathrm{a}$ \\
\hline \multirow{2}{*}{ 'SV2' } & Shoot tip & $20.7 \mathrm{~b}$ & $79.3 \mathrm{~b}$ & - \\
\hline & Dormant bud & $71.0 \mathrm{a}$ & $29.0 \mathrm{~b}$ & $0.0 \mathrm{~d}$ \\
\hline
\end{tabular}

Note: Numbers $\frac{\text { followed by a different letter are significantly different at } \mathrm{P}<0.05}{\text {, }}$ according to Duncan's multiple range tests standard cherry rootstock 'Gisela 6' (Tab. 2). No significant differences among the multiplication index and height of the newly formed shoots between solid and double-phase medium were noted in 'D3' and 'M1' genotype. In contrast, shoot height of the 'D6' genotype was considerably affected by the addition of liquid medium. Plant height is very important parameter during acclimatization and survival of multiplied plants. After the multiplication phase, in the previously described treatment, Bošnjaković et al. (2013) rootstock selections were placed on DKW hormone-free medium, aimed at improving shoot elongation before rooting. Although some authors reported achieving shoot elongation prior to rooting in the treatments based on BA lower levels (Zilkah et al., 1992; Szczygiel and Wojda, 2010), any improvements in shoot elongation could not observe (unpublished data). However, DKW hormone-free medium had a positive influence on the elongation of multiplied shoots, in line with Pruski et al. (2005). The present results show that using the double-phase medium, it is possible to reduce the time and in vitro manipulation during subculturing, thus eliminating the phase of subculturing to fresh medium. This finding is in line with the results reported by Dobránszki and Teixeira da Silva (2010) and Scherwinski-Pereira et al. (2012). In addition, these authors pointed out that usage of liquid medium could reduce the micropropagation cost, which is an important parameter in commercial plant propagation. Moreover, in double-phase medium, the explants take up nutrients, hormones, and plant growth regulators faster and from both layers (Gupta et al., 2005; George and Davids, 2008; Scherwinski-Pereira et al., 2012).

In 'SV1' and 'SV2', while a greater multiplication index (5.4 and 6.7, respectively) was achieved on solid medium, using the double-phase medium resulted in a significant increase in newly formed shoot height (by 2.5 and 2.8, respectively). Positive effects of using a double-phase medium on multiplication and height of multiplied shoots was investigated in pineapple (Scherwinski-Pereira et al., 2012), vanilla (De Oliveira et al., 2013), apple (Litwinczuk, 2000), and cherry rootstocks (Dziedzic and Malodobry, 2006). In this study, only 'M1' was negatively affected by the use of double-phase medium as the newly formed shoots started to yellow and vitrify. Paquez and Boxus (1987) reported higher vitrification and production of dry weight in larger quantities in samples grown on liquid than those maintained on a similar solid medium. P. mabaleb is well known for its susceptibility to water logging in in vivo conditions as well. The growth and development of shoots was affected by addition of active charcoal to both liquid and solid medium, due to its capacity for adsorbing the inhibitory substances in culture medium, as well as the excess cytokinins (Jona and Vigliocco, 1985; Pan and van Staden, 1998; Thomas, 2008). Positive effects of active charcoal in micropropagation of Prunus rootstocks were also reported by Dradi et al. (1996), Szczygiel and Wojda (2010) and Druart (2013). Number of leaves reflects the shoot quality and thus its potential for further subcultivation. In 'D3' and 'D6' genotypes, no significant differences in the numbers of leaves, leaf length and leaf width were noted between solid and double-phase medium. On the other hand, significantly higher number of leaves was found in 'Gisela 6' when double-phase medium was used. In 'SV1' and 'SV2', as well as 'M1', the number of leaves was higher on solid than double-phase 
491

medium, although this parameter is genotype-dependent.

Rooting ability differed among investigated species, and among investigated genotypes within the same species. During subculturing, all explants of 'D3' genotype died due to bacterial contamination; thus, rooting trials could not be conducted due to the insufficient number of plants. For all investigated genotypes, Fe-EDDHA was added to the rooting medium in the concentration of $200 \mathrm{mg} \mathrm{l}^{-1}$, as this enables better rooting, produces plantlets of higher quality, and promotes correction of shoot-tip necrosis. Iron is required for chlorophyll biosynthesis, and its deficiency is often manifested as leaf chlorosis (Dunlap and Robacker, 1988; Gaspar et al., 1992), which can lead to necrosis (van der Salm et al., 1994). Ca content is one of the most important factors for the development of shoot tip necrosis (Bairu et al., 2009). It has been established that the application of iron results in an increase in the $\mathrm{Ca}$ content in the peach leaf (Fernández et al., 2008), which can explain the positive effect of iron on the reduction in the prevalence of shoot tip necrosis. The auxin produced in the shoot, basipetally transported towards the root system (Ljung et al., 2001), plays a crucial role in the root development (Aloni et al., 2006). Shoot tip necrosis most likely disrupts the auxin production and flow, which negatively affects the rooting. This effect was previously reported by Xing et al. (1997), whose study demonstrated that higher rooting rate was associated with lower prevalence of shoot-tip necrosis.

At the same IBA concentration, adding Fe-EDDHA to the rooting medium resulted in a significantly higher rooting percentage in 'Gisela 6' and 'D6' genotype (Tab. 3). As 'Gisela' rootstock series is mainly propagated by micropropagation, a successful protocol for 'Gisela 6 ' was reported by Vujović et al. (2009), Hossini et al. (2010), Aghaye et al. (2013) and Sarropoulou et al. (2013), who achieved rooting percentage exceeding 80\%, with $1 \mathrm{mg} \mathrm{l}^{-1} \mathrm{IBA}$ concentration, which is in the line with the present results.

In our study, 'M1' selection has shown maximum rooting ability, and has produced both the highest number of roots and the greatest total root length at $0.8 \mathrm{mg} \mathrm{l}^{-1}$ IBA concentration, which is in line with the findings of Dradi et al. (1996). On the other hand, in $P$. fruticosa genotypes, satisfactory rooting was achieved at significantly higher concentrations of auxins - for 'SV1' and 'SV2', the optimum concentration was $3.5 \mathrm{mgl}^{-1}$ and $2.5 \mathrm{mg} \mathrm{l}^{-1}$ IBA, respectively (Tab. 3). When lower concentrations of IBA were used, genotypes tended to show high cell division, producing callus. However, roots were either absent, or present in a very small number, with evident symptoms of shoot-tip necrosis. In 'SV1' genotype, FeEDDHA significantly increased the percentage of rooted plants (from $60 \%$ to $85.6 \%$ ), when $2 \mathrm{mg}^{-1}$ IBA concentration was used, while at the 1 and $2 \mathrm{mgl}^{-1} \mathrm{IBA}$, without Fe-EDDHA, rooting was not achieved in 'SV2'. While increasing the IBA concentration increased the percentage of rooted plants, it was significantly higher in the presence of Fe-EDDHA. Pruski et al. (2005) reported that using the combination of IBA and NAA resulted in 79\% rooting for $P$. fruticosa, while Szczygiel and Wojda (2010) achieved only $34 \%$ of rooted plants with $2 \mathrm{mgl}^{-1}$ IBA. Increasing auxin concentration resulted in a somewhat increased number of roots and total length. In 'M1' and 'SV2', maximum number of roots, as well as the greatest total root length, was noted at IBA concentrations of 0.8 and $3 \mathrm{mg} \mathrm{l}^{-1}$,

Tab. 2. Multiplication parameters on solid (S) and double-phase (DP) medium

\begin{tabular}{|c|c|c|c|c|c|c|c|c|c|c|}
\hline \multirow[t]{2}{*}{ Genotype } & \multicolumn{2}{|c|}{ Multiplication index } & \multicolumn{2}{|c|}{$\begin{array}{l}\text { Height of proliferated } \\
\text { shoots }(\mathrm{cm})\end{array}$} & \multicolumn{2}{|c|}{$\begin{array}{c}\text { Number of } \\
\text { leaves }\end{array}$} & \multicolumn{2}{|c|}{$\begin{array}{l}\text { Leaf length } \\
(\mathrm{cm})\end{array}$} & \multicolumn{2}{|c|}{$\begin{array}{l}\text { Leaf width } \\
\mathrm{cm})\end{array}$} \\
\hline & $S$ & DP & $S$ & DP & $S$ & DP & $S$ & $\mathrm{DP}$ & $S$ & DP \\
\hline 'Gisela 6' & $2.7 \mathrm{de}$ & $3.9 \mathrm{c}$ & $2.2 \mathrm{c}$ & $3.5 \mathrm{a}$ & $15.2 \mathrm{def}$ & $19.3 \mathrm{~b}$ & $1.5 \mathrm{a}$ & $1.2 \mathrm{~d}$ & $0.8 \mathrm{ab}$ & $0.8 \mathrm{~b}$ \\
\hline 'D3' & $1.8 \mathrm{f}$ & $1.7 \mathrm{f}$ & $1.0 \mathrm{e}$ & $0.8 \mathrm{ef}$ & $17.5 \mathrm{bcd}$ & $17.9 \mathrm{bc}$ & $1.3 \mathrm{bc}$ & $1.4 \mathrm{~b}$ & $0.5 \mathrm{e}$ & $0.6 \mathrm{de}$ \\
\hline 'D6' & $1.9 \mathrm{ef}$ & $2.4 \mathrm{def}$ & $1.4 \mathrm{~d}$ & $2.0 \mathrm{c}$ & $15.9 \mathrm{cde}$ & $16.3 \mathrm{cde}$ & $1.3 \mathrm{bc}$ & $1.4 \mathrm{~b}$ & $0.5 \mathrm{e}$ & $0.5 \mathrm{e}$ \\
\hline 'M1' & $3.0 \mathrm{~d}$ & $2.2 \mathrm{def}$ & $0.9 \mathrm{ef}$ & $0.7 \mathrm{f}$ & $17.5 \mathrm{bcd}$ & $13.4 \mathrm{f}$ & $1.0 \mathrm{e}$ & $1.2 \mathrm{~cd}$ & $0.9 \mathrm{a}$ & $0.6 \mathrm{~d}$ \\
\hline 'SV1' & $5.4 \mathrm{~b}$ & $3.9 \mathrm{c}$ & $0.9 \mathrm{ef}$ & $2.5 b$ & $23.7 \mathrm{a}$ & $17.4 \mathrm{bcd}$ & $1.3 \mathrm{bcd}$ & $1.3 \mathrm{bc}$ & $0.5 \mathrm{e}$ & $0.5 \mathrm{e}$ \\
\hline 'SV2' & $6.7 \mathrm{a}$ & $4.1 \mathrm{c}$ & $1.4 \mathrm{~d}$ & $2.8 \mathrm{~b}$ & $18.2 \mathrm{bc}$ & $14.6 \mathrm{ef}$ & $1.3 \mathrm{bcd}$ & $1.4 \mathrm{~b}$ & $0.5 \mathrm{e}$ & $0.7 \mathrm{c}$ \\
\hline
\end{tabular}

Note: Numbers followed by a different letter are significantly different at $\mathrm{P}<0.05$, according to Duncan's multiple range tests

Tab. 3. Effect of auxins and Fe-EDDHA on rooting percentage, number of roots and total root length

\begin{tabular}{|c|c|c|c|c|c|}
\hline Genotype & IBA $\left(\mathrm{mgl}^{-1}\right)$ & Fe-EDDHA $\left(\mathrm{mg} \mathrm{l}^{-1}\right)$ & Percent of rooting (\%) & Number of roots & Total root length $(\mathrm{cm})$ \\
\hline \multirow{2}{*}{ 'Gisela 6' } & 1 & / & $61.7 \mathrm{e}$ & 6.9efghi & $7.5 \mathrm{efg}$ \\
\hline & 1 & 200 & $92.7 \mathrm{ab}$ & $10.9 \mathrm{bcd}$ & $13.9 \mathrm{~cd}$ \\
\hline \multirow{2}{*}{ 'D6’ } & 1 & / & $42.0 \mathrm{f}$ & 8.0defgh & 9.3 defg \\
\hline & 1 & 200 & $60.0 \mathrm{e}$ & $8.9 \mathrm{cdefg}$ & 11.0def \\
\hline \multirow{3}{*}{ 'M1' } & 0.5 & 200 & $83.9 \mathrm{bcd}$ & $5.2 \mathrm{hi}$ & 7.0efg \\
\hline & 0.8 & 200 & $96.7 \mathrm{a}$ & 8.9cdefg & $8.8 \mathrm{defg}$ \\
\hline & 1 & 200 & $80.0 \mathrm{~d}$ & 6.5efghi & $4.4 \mathrm{~g}^{\circ}$ \\
\hline \multirow{8}{*}{ ‘SV1' } & 0.5 & / & $6.9 \mathrm{i}$ & $4.1 \mathrm{i}$ & $12.3 \mathrm{cdef}$ \\
\hline & 1 & / & $29.4 \mathrm{~g}$ & $3.6 \mathrm{i}$ & $10.8 \mathrm{def}$ \\
\hline & 2 & / & $60.0 \mathrm{e}$ & $4.5 \mathrm{i}$ & $7.0 \mathrm{efg}$ \\
\hline & 1 & 200 & $18.3 \mathrm{~h}$ & 6.0fghi & $8.8 \mathrm{defg}$ \\
\hline & 2 & 200 & $85.6 \mathrm{bcd}$ & $9.1 \mathrm{cdef}$ & $12.0 \mathrm{cdef}$ \\
\hline & 2.5 & 200 & $82.7 \mathrm{bcd}$ & $9.1 \mathrm{cdef}$ & 10.6def \\
\hline & 3 & 200 & $85.0 \mathrm{bcd}$ & $9.6 \mathrm{cde}$ & $12.7 \mathrm{cde}$ \\
\hline & 3.5 & 200 & $91.8 \mathrm{abc}$ & $13.7 \mathrm{~b}$ & $16.9 b c$ \\
\hline \multirow{8}{*}{ 'SV2' } & 0.5 & / & 0 & / & l \\
\hline & 1 & / & 0 & / & / \\
\hline & 2 & I & 0 & / & / \\
\hline & 1 & 200 & $5.6 \mathrm{i}$ & 6.5 efghi & $6.1 \mathrm{fg}$ \\
\hline & 2 & 200 & $18.3 \mathrm{~h}$ & 5.9fghi & $8.5 \mathrm{defg}$ \\
\hline & 2.5 & 200 & $85.0 \mathrm{bcd}$ & 5.6ghi & $10.5 \mathrm{defg}$ \\
\hline & 3 & 200 & $80.0 \mathrm{~d}$ & $18.9 \mathrm{a}$ & $33.1 \mathrm{a}^{\circ}$ \\
\hline & 3.5 & 200 & $81.7 \mathrm{~cd}$ & $11.6 \mathrm{bc}$ & $20.7 b$ \\
\hline
\end{tabular}




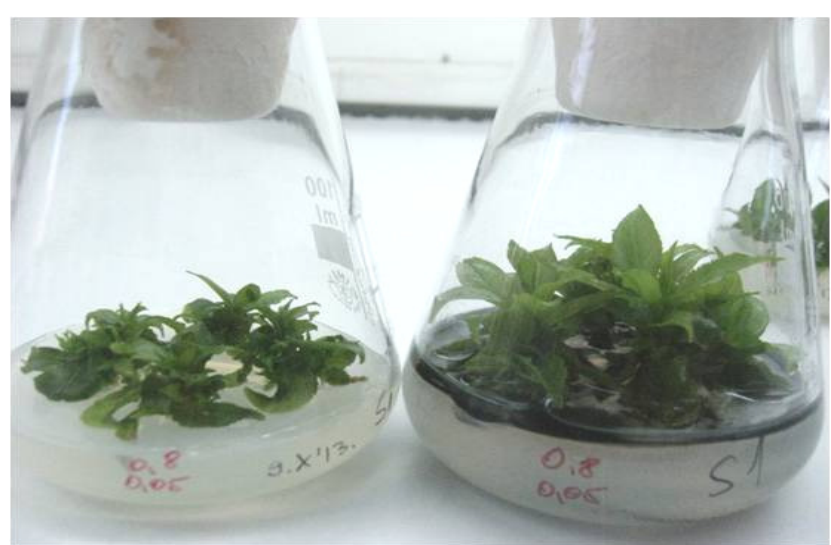

Fig. 1. The differences in the effect of the solid and doublephase multiplication medium applied to $P$. fruticosa 'SV1' selection on the proliferated shoot height

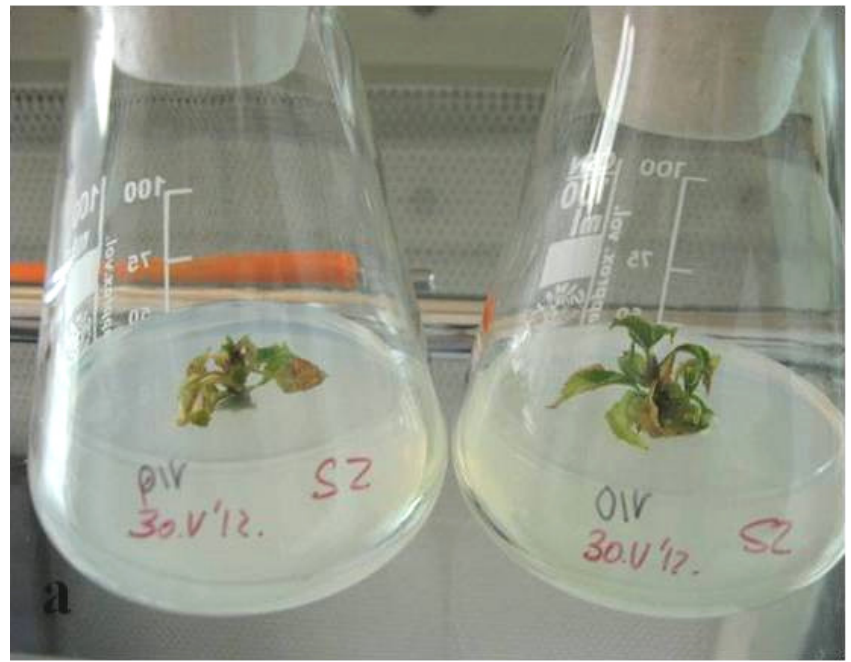

respectively, after which a decline was observed. In contrast, in 'SV1', maximum number of roots and total root length was measured at the highest applied IBA concentration (Tab. 3). Similar results were reported by Shibli et al. (1997), who stated that number of roots and root length increased as the IBA concentration increased. However, according to other authors, high concentrations of applied auxins could inhibit root growth and elongation (Loach, 1988; Taiz and Zeiger, 2006; Zhao et al., 2014). In 'Gisela 6 and 'D6', greater number of roots and total root length was measured in the presence of FeEDDHA, thus conforming to the results of Dimassi et al. (2003). Iron is a part of peroxidase, an enzyme responsible for adventitious root formation (Gaspar et al., 1992; Hatzilazarou et al., 2006). Positive effects of Fe-EDDHA on rooting of peach rootstock GF-677 were reported by Molassiotis et al. (2003), Balla and Kirilla (2006), Antonopoulou et al. (2007) and Hasan et al. (2010).

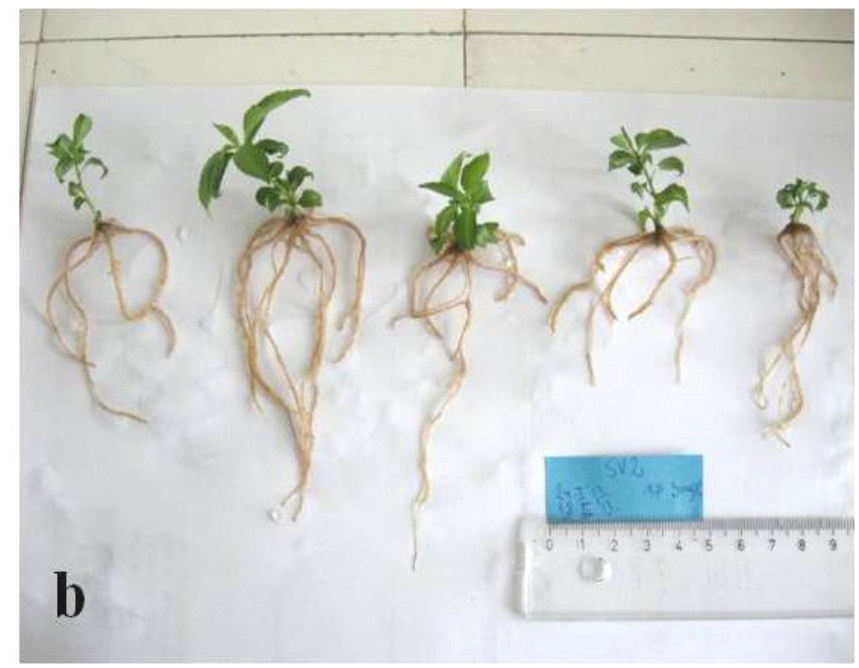

Fig. 2. The effect of Fe-EDDHA on the rooting of $P$. fruticosa 'SV2' selection: a) without Fe-EDDHA plants showing symptoms of shoot tip necrosis, b) with Fe-EDDHA plants with well developed roots

\section{Conclusion}

As micropropagation is a process characterized by an interaction of different components, it is difficult to optimize the culture medium for investigated germplasm. Thus, it is not possible to establish a uniform protocol that can be applied to propagation within and between species, as it is strongly genotype-dependent. Thus, the effect of the medium should be studied for each genotype separately. Considering the fact that standard rootstocks for sweet and sour cherry are mostly propagated by micropropagation, vegetatively propagated selections of $P$. mahaleb, $P$. cerasus and $P$. fruticosa have been successfully achieved through a large number of attempts to establish cultures in vitro. This was necessary, as all samples originated from their natural habitat, and thus subject to uncontrolled contamination. As, in this work, a large number of rooted and acclimatized selections has been achieved, the micropropagation protocol has been optimized. The protocols discussed here were given a priority over softwood cuttings, as the aim was to establish a faster process for implementing newly propagated selections in a breeding program. The vegetative propagation method investigated in this study presents the best and the fastest genotype propagation method. Ljubojević et al. (2013) proved that dwarf rootstocks are a promising material, due to their anatomical, morphological and physiological parameters. This propagation method provided sufficient number of rootstocks with special combining abilities, which are currently being tested in field grafting trials.

\section{Acknowledgments}

This work was supported by the Ministry of Education, Science, and Technological Development of Serbia, as a part of the project 'Selection of sweet and sour cherry dwarfing rootstocks and development of intensive cultivation technology based on sustainable agricultural principles' (grant number 31038).

\section{References}

Aghaye RNM, Yadollahi A, Moeini A, Sepahvand S (2013). In vitro culture of Gisela 6 semi-dwarf rootstock. J Biol Environ Sci 7:57-64. 
493

Aloni R, Aloni E, Langhans M, Ullrich CI (2006). Role of cytokinin and auxin in shaping root architecture: regulating vascular differentiation, lateral root initiation, root apical dominance and root gravitropism. Ann Bot-London 97:883893.

Antonopoulou C, Dimassi K, Therios I, Chatzissavvidis C, Papadakis E (2007). The effect of Fe-EDDHA and of ascorbic acid on in vitro rooting of the peach rootstock GF-677 explants. Acta Physiol Plant 29:559-561.

Bairu MW, Stirk WA, van Staden J (2009). Factors contributing to in vitro shoot-tip necrosis and their physiological interactions. Plant Cell Tiss Org Cult 98:239-248.

Balla I, Kirilla Z (2006). Micropropagation of peach rootstocks and cultivars. Acta Hort 725:511-516.

Bošnjaković D, Ognjanov V, Ljubojević M, Barać G, Predojević M, Mladenović E, Čukanović E (2012a). Biodiversity of wild fruit species of Serbia. Genetika-Serbia 44:81-90.

Bošnjaković D, Ognjanov V, Pranjić A, Ljubojević M, Barać G, Mladenović E, Čukanović J (2012b). Vegetative propagation of autochthonous cherry germplasm. 14th Serbian congress of fruit and grapevine producers with international participation, Vrnjačka Banja, Serbia 101.

Bošnjaković D, Ognjanov V, Barać G, Ljubojević M, Pranjić A, Dugalić K (2013). Micropropagation of low-vigorous rootstock selections for sweet and sour cherry. J Pomol 47:121-128.

De Oliveira SOD, Sayd RM, Balzon TA, Scherwinski-Pereira JE (2013). A new procedure for in vitro propagation of vanilla (Vanilla planifolia) using a double-phase culture system. Sci Hortic-Amsterdam 161:204-209.

Dimassi K, Chouliaras V, Diamantidis G, Therios I (2003). Effect of iron and auxins on peroxidase activity and rooting performance of three citrus rootstocks in vitro. J Plant Nutr 26:1023-1034.

Dobránszki J, Teixeira da Silva JA (2010). Micropropagation of apple - A Review. Biotechnol Adv 28:462-488.

Dradi G, Vito G, Standardi A (1996). In vitro mass propagation of eleven Prunus mahaleb ecotypes. Acta Hort 410:477-484.

Driver JA, Kuniyuki AH (1984). In vitro propagation of Paradox walnut rootstock. HortScience 19:507-509.

Druart P (2013). Micropropagation of Prunus Species Relevant to Cherry Fruit Production, p. 119-136. In: Lambardi M, Ozudogru EA, Jain SM (Eds.). Protocols for micropropagation of selected economically-important horticultural plants. Humana Press, New York.

Dunlap JR, Robacker KM (1988). Nutrient salts promote lightinduced degradation of indole-3-acetic acid in tissue culture media. Plant Physiol 88:379-382.

Dziedzic E, Malodobry M (2006). Vegetative cherry rootstocks in tissue culture. Scientific Works of the Lithuanian Institute of Horticulture and Lithuanian University of Agriculture. Sodininkysté ir Daržininkysté 25:77-84.

Fernández V, Del Rio V, Pumariño L, Igartua E, Abadía J, Abadía
A (2008). Foliar fertilization of peach (Prunus persica (L.) Batsch) with different iron formulations: Effects on regreening, iron concentration and mineral composition in treated and untreated leaf surfaces. Sci Hortic-Amsterdam 117:241-248.

Feucht W, Dausend B (1976). Root induction in vitro of easy-toroot Prunus pseudocerasus and difficult-to-root Prunus avium. Sci Hortic-Amsterdam 4:49-54.

Gaspar T, Kevers C, Hausman JF, Berthon JY, Ripetti V (1992). Practical uses of peroxidase activity as a predictive marker of rooting performance of micropropagated shoots. Agronomie 12:757-765.

George EF, Davies W (2008). Effects of the Physical Environment, p. 425. In: George FE, Hall AM, De Klerk GJ (Eds.). Plant propagation by tissue culture $3^{\text {rd }}$ ed. Springer, Netherlands.

George EF, Debergh PC (2008). Micropropagation: Uses and Methods, p. 35-36. In: George FE, Hall AM, De Klerk GJ (Eds.). Plant propagation by tissue culture $3^{\text {rd }}$ ed. Springer, Netherlands.

Gupta PK, Timmis R (2005). Mass propagation of conifer trees in liquid cultures-progress towards commercialization. Plant Cell Tiss Org Cult, 81:339-346.

Hasan SZU, Ahmad T, Hafiz IA, Hussain IA (2010). Direct plant regeneration from leaves of Prunus rootstock GF-677 (Prunus amygdalus $\mathrm{x}$ P. persica). Pak J Bot 42:3817-3830.

Hassan AKMS, Roy SK (2005). Micropropagation of Gloriosa superba L. through high frequency shoot proliferation. Plant Tissue Cult 15:67-74.

Hatzilazarou SP, Syros TD, Yupsanis TA, Bosabalidis AM, Economou AS (2006). Peroxidases, lignin and anatomy during in vitro and ex vitro rooting of gardenia (Gardenia jasminoides Ellis) microshoots. J Plant Physiol 163:827-836.

Hossini AD, Moghadam EG, Anahid S (2010). Effect of medium cultures and plant growth regulators in micropropagation of Gisela 6. Ann Biol Res 1:135-141.

Jona R, Vigliocco R (1985). Axillary bud culture of peach. Acta Hort 173:223-228.

Kaushal N, Modgil M, Thakur M, Sharma DR (2005). In vitro clonal multiplication of an apple rootstock by culture of shoot apices and axillary buds. Indian J Exp Biol 43:561-565.

Litwinczuk W (2000). Efficiency of a double-phase medium in micropropagation of semi-dwarf apple rootstocks M.26, MM.106 and P14. J Fruit Ornam Plant Res 8:97-106.

Ljubojević M, Ognjanov V, Zorić L, Maksimović I, Merkulov Lj, Bošnjaković D, Barać G (2013). Modeling of water movement trough cherry plant as preselecting tool for prediction of tree vigor. Sci Hortic-Amsterdam 160:189-197.

Ljung K, Bhalerao RP, Sandberg G (2001). Sites and homeostatic control of auxin biosynthesis in Arabidopsis during vegetative growth. Plant J 28:465-474.

Loach K (1988). Hormone applications and adventitious root formation in cuttings: A critical review. Acta Hort 227:126- 
133.

Molassiotis AN, Dimassi K, Therios I, Diamantidis G (2003). FeEDDHA promotes rooting of rootstock GF-677 (Prunus amygdalis $\times P$. persica) explants in vitro. Biol Plant 47:141-144.

Molassiotis AN, Dimassi K, Diamantidis G, Therios I (2004). Changes in peroxidases and catalase activity during in vitro rooting. Biol Plant 48:1-5.

Murashige T, Skoog F (1962). A revised medium for rapid growth and bioassays with tobacco tissue culture. Physiol Plant 15:473-442.

Pan MJ, van Staden J (1998). The use of charcoal in in vitro culture-A review. Plant Growth Regul 26:155-163.

Paquez M, Boxus Ph (1987). Vitrification: Review of literature. Acta Hort 212:155-166.

Paunović G (2008). The selection of vegetative rootstocks for stone fruits. Acta Agric Serb 13:17-24.

Perez-Tornero O, Burgos L, Egea J (1999). Introduction and establishment of apricot in vitro through regeneration of shoots from meristem tips. In Vitro Cell Dev-Pl 35:249-253.

Pruski K, Astatkie T, Nowak J (2005). Tissue culture propagation of Mongolian cherry (Prunus fruticosa L.) and Nanking cherry (Prunus tomentosa L.). Plant Cell Tiss Org Cult 82:207-211.

Rustaei M, Nazeri S, Ghadimzadeh M, Hemmaty S (2009). Effect of phloroglucinol, medium type and some component on in vitro proliferation of dwarf rootstock of apple (Malus domestica). Int J Agric Biol 11:193-196.

Ružić D, Sarić M, Cerović R, Ćulafić Lj (2000). Relationship between the concentration of macroelements, their uptake and multiplication of cherry rootstock Gisela 5 in vitro. Plant Cell Tiss Org Cult 63:9-14.

Ružić D, Cerović R, Vujović T (2010). Establishment of aseptic culture in vitro for new vegetative rootstocks for cherry, pear and plum. J Pomol 44:35-41.

Sarropoulou V, Dimassi-Theriou K, Therios I (2013). Indole-3butyric acid and myo-inositol impacts on in vitro rooting of the cherry rootstocks CAB-6P and Gisela 6. Biol Plant 57:613-619.

Schenk RU, Hildebrandt AC (1972). Medium and techniques for induction and growth of monocotyledonous and dicotyledonous plant cell cultures. Can J Bot 50:199-204.

Scherwinski-Pereira JE, Araruna Lima EC, Da Silva TL, Gomes Mesquita AG, Maciel AS, Da Silva Costa FH (2012). Doublephase culture system for large scale production of pineapple. Plant Cell Tiss Org Cult 109:263-269.
Sedlak J, Paprstein F, Erbenova M (2008). In vitro propagation of PHL dwarfing sweet cherry rootstocks. Acta Hort 795:395400.

Shibli RA, Ajlouni MM, Jaradat A, Aljanabi S, Shatnawi M (1997). Micropropagation in wild pear (Pyrus syricca). Sci Hortic-Amsterdam 68:237-242.

Szczygiel K, Wojda T (2010). Micropropagation of sour cherry (Cerasus fruticosa Pallas). For Res Pap 71:351-355.

Štefančič M, Vodnik D, Štampar F, Osterc G (2007). The effect of a fogging system on the physiological status and rooting capacity of leafy cuttings of woody species. Trees 21:491-496.

Taiz L, Zeiger E (2006). Plant physiology. $4^{\text {th }}$ Ed. Sinauer Associates Inc Sunderland, MA, 439, $451 \mathrm{p}$.

Thomas TD (2008). The role of activated charcoal in plant tissue culture. Biotechnol Adv 26:618-631.

Trejgell A, Libront I, Tretyn A (2012). The effect of Fe-EDDHA on shoot multiplication and in vitro rooting of Carlina onopordifolia Besser. Acta Physiol Plant 34:2051-2055.

van der Salm TPM, van der Toorn CJG, Hanisch ten Cate ChH, Dubois LAM, de Vries DP, Dons JMH (1994). Importance of the iron chelate formula for micropropagation of Rosa bybrida L.'Moneyway'. Plant Cell Tiss Org Cult 37:73-77.

Vujović T, Ružic D, Cerović R, Dordjević M (2009). The influence of imidazole fungicide on multiplication on in vitro of low vigorous sweet cherry rootstock Gisela 6. J Pomol 43:87-93.

Vujović T, Ružić D, Cerović R (2012). In vitro multiplication as influenced by repeated subculturing of shoots of contemporary fruit rootstocks. Hortic Sci 39:101-107.

Xing Z, Satchwell MF, Powell WA, Maynard CA (1997). Micropropagation of American chestnut: increasing rooting rate and preventing shoot-tip necrosis. In Vitro Cell Dev-Pl 33:43-48.

Zhao X, Zheng H, Li S, Yang C, Jiang J, Liu G (2014). The rooting of poplar cuttings: a review. New Forest 45:21-34.

Zilkah S, Faingersh E, Rotbaum A (1992). In vitro propagation of three M x M (Prunus avium x P. mahaleb) cherry rootstock. Acta Hort 314: 93-97. 